\title{
KETIDAKTERATURAN MINUM OBAT MDT PADA PENDERITA KUSTA DI RUMAH SAKIT KUSTA DR. SITANALA, TANGERANG-BANTEN
}

\author{
Petrus Geroda Beda Ama \\ Program studi S1 Kesehatan Masyarakat Universitas MH Thamrin \\ petrusgeroda@gmail.com
}

\begin{abstract}
ABSTRAK
Jumlah penderita Kusta di RSK Dr. Sitanala cenderung fluktuatif, baik di rawat inap maupun di rawat jalan. Hasil wawancara dengan petugas kesehatan di salah satu ruang rawat inap, diperoleh bahwa banyak penderita kusta yang tidak teratur Minum Obat MDT. Jenis penelitian ini adalah kuantitatif dengan pendekatan studi Cross Sectional, dengan total populasi sama dengan sampel yaitu 90 sampel. Hasil penelitian menunjukan Variabel yang berhubungan adalah : Jenis Kelamin dengan $\mathrm{P}$ value : 0,003 dan OR : 13,000, CI : 1,619-04,377; Pengetahuan dengan P. Value : 0,010 dan OR = 3,726 CI : 1,439-,650; Pendidikan dengan P. Value : 0,007 dan OR = 4,773 dengan CI: 1,462-15,582); Sikap dengan P. Value : 0,007 dan OR = 3,636 dengan CI: 1,489-8,881; Dukungan Keluarga dengan P Value : 0,002 dan OR = 4,229 dengan CI: (1,734-10,310); Tingkat Ekonomi dengan P.value :0,007 dan OR:0,159 dengan CI: 0,041-0,619. Sementara variabel yang tidak berhubungan adalah : Umur, dengan P. Value : 0,777; dan Dukungan petugas kesehatan dengan P Value : 0,866. Perlu dilakukan KIE ( Komunikasi, Informasi dan Edukasi) tentang kepatuhan minum obat terutama bagi penderita laki-laki agar lebih termotivasi untuk sembuh.

Daftar Pustaka: 11 ( 2009-2012)
\end{abstract}

Kata Kunci: Ketidakteraturan minum obat MDT

\section{PENDAHULUAN}

Penyakit Kusta merupakan penyakit menular yang dapat menimbulkan masalah yang sangat kompleks. Masalah yang dimaksud bukan hanya dari segi medis tetapi meluas sampai masalah sosial, ekonomi, budaya keamanan dan ketahanan social. (Depkes, 2012)

Penyakit Kusta tersebar di seluruh dunia dengan endemisitas yang berbeda. Angka prevalensi kusta di dunia pada tahun 2000 sebanyak 1,25 kasus per 10.000 penduduk dan diantaranya terdapat 720.000 kasus baru. Diperkirakan kasus baru akan bertambah sebesar 2.500.000 penderita pada periode 2000-2005. (Agung, 2010)

Distribusi angka penemuan kasus baru kusta di dunia yang terlapor di WHO pada awal tahun 2012 dimana jumla kasus baru kusta didunia pada tahun 2012 adalah sekitar 219.075 kasus. Dari jumlah tersebut paling banyak terdapat di regional Asia Tenggara yaitu 160.132 kasus, diikuti regional Amerika yaitu 36.832 kasus, regional Afrika yaitu 12.673 kasus dan sisanya berada di regional lain dunia (Depkes, 2012). Indonesia masih menjadi penyumbang kasus baru kusta nomor 3 di dunia setelah India dan Brazil. Laporan WHO pada tahun 2011, Indonesia menjadi peyumbang kasus baru kusta yang terdeteksi sebanyak 17.012 kasus. (WHO, 2011).

Tingginya kasus kusta di Indonesia dikarenakan adanya stigma, dan diskriminasi terhadap orang yang pernah mengalami kusta. Hal ini mengakibatkan makin sulitnya menjangkau penderita untuk pengobatan. (Agung, 2010).

Provinsi Banten juga merupakan salah satu provinsi yang tercatat berpotensi menyumbang kasus baru kusta cukup besar. Laporan tahunan, tahun 2012 dalam profil kesehatan Provinsi Banten terlihat angka penemuan kasus baru (New Case Detection Rate ) per 100.000 penduduk tercatat sebesar 7,38. Artinya diantara 100.000 penduduk ditemukan ada 7-8 kasus baru. Adapun kasus kusta di provinsi Banten paling banyak di temukan di kabupaten Tangerang dengan 24 kasus baru, diikuti kabupaten serang yaitu 180 kasus baru, kabupaten kota tangerang sebanyak 99 kasus. (Dinkes Banten, 2012). 
Rumah Sakit Kusta (RSK) Dr. Sitanala berlokasi di Kota Tangerang Provinsi Banten dengan menempati lahan seluas 54 hektar, merupakan Unit Pelaksana Teknis dilingkungan Depkes RI. Adapun Jumlah penderita kusta di RSK Dr. Sitanala pada tahun 2009 tercatat sebanyak 3321 penderita, tahun 2010 sebanyak 2722 penderita dan tahun 2011 tercatat 1363 penderita yang menjalani pengobatan rawat inap, sedangkan jumlah kunjungan rawat jalan pada tahun 2009 sebanyak 10421 penderita, tahun 2010 sebanyak 8516 penderita dan tahun 2011 sebanyak 9030,dengan ratarata kunjungan perbulan sebanyak 600-800 penderita. (RSK Dr. Sitanala, 2012).

Dari data tersebut diatas diketahui masih banyaknya jumlah penderita yang berada di ruang rawat inap, serta adanya kenaikan jumlah kunjungan di unit rawat jalan RSK.Dr. Sitanala Tangerang Banten. Berdasarkan hasil wawancara bersama pengelola ruangan rawat inap, bahwa masih banyaknya jumlah penderita kusta tersebut faktor utamanya adalah dikarenakan tidak teraturnya penderita dalam hal minum obat. Oleh karena itu diperlukan langkah konkrit berupa peningkatan kualitas diagnosa penderita, pengawasan pengobatan sampai penderita diyatakan selesai masa pengobatan (RFT: Release From Treatmen) dan perencanaan kebutuhan obat yang rasional. (Prastiwi, 2011)

Dari uraian diatas maka penulis ingin melakukan penelitan untuk mengetahui Faktor-Apa Saja Yang Berhubungan dengan Ketidakteraturan Minum Obat MDT pada Penderita Kusta di Rumah Sakit Kusta Dr. Sitanala, Tangerang-Banten.

\section{METODE}

Jenis penelitian yang digunakan adalah kuantitatif dengan menggunakan pendekatan studi Cross Sectional, dilakukan di Rumah Sakit Kusta Dr.Sitanala, Tangerang-Banten. Penentuan sampel menggunakan teknik Total Sampling, dimana jumlah populasi sebanyak 90 orang semuanya dijadikan sampel. Data yang digunakan berupa primer dan sekunder. Data primer di kumpulkan secara langsung dari obyek penelitian melalui wawancara yang mengacu pada kuisioner terkait data tentang, umur, jenis kelamin, tingkat pendidikan penderita, pengetahuan penderita, sikap penderita, dukungan petugas kesehatan, dukungan keluarga dan tingkat ekonomi. Sementara data Sekunder diperoleh dengan melihat buku kunjungan pasien, dan catatan petugas kesehatan yang berhubungan ketidakteraturan minum obat $M D T$. Pengolahan data dilakukan dengan bantuan aplikasi perangkat lunak computer. Sementara analisa data yang dilakukan adalah Analisa Univariat dan Bivariat

Untuk mengetahui apakah hipotesis (H0) yang diajukan sebelumnya ditolak atau diterima, maka dilakukan uji statistik dengan ketentuan, bila $\mathrm{p}$ value $\leq \alpha(0,05)$ maka H0 ditolak, artinya ada perbedaan yang bermakna, bila $\mathrm{p}$ value $>\alpha(0,05)$ maka, H0 diterima, artinya tidak ada perbedaan yang bermakna. (Hastono, 2007).

\section{HASIL DAN PEMBAHASAN}

\section{Analisis Univariat}

Hasil penelitian diketahui dari 90 orang jumlah total responden ada sebanyak 39 orang (43,3\%) tidak teratur minum obat MDT, sedangkan ada sebanyak 51 orang $(56,7 \%)$ teratur minum obat. Diantara semua responden tersebut, 38,9\% berumur antara 15-29 tahun dan 84,4\% berjenis kelamin laki-laki. Sebanyak 63,3\% berpengetahuan kurang dan 75,6\% berpendidikan rendah. 54,4\% diantaranya mempunyai sikap negatif dan $31,1 \%$ menyatakan bahwa kurang ada dukungan dari petugas kesehatan. Sebanyak 42,2\% menyatakan bahwa 
kurang ada dukungan dari keluarga dan hampir sebagian besar diantaranya yaitu 84,4 \% responden mempunyai tingkat ekonomi yang rendah.

Untuk lebih jelas hasil analisa univariat dapat dilihat pada tabel 1.

Tabel 1

Distribusi Frekuensi Variable Indenpenden Dan Dependen

\begin{tabular}{lccc}
\hline Variabel & Kategori & Jumlah (n) & Presentase (\%) \\
\hline Ketidakteraturan & Tidak Teratur & 39 & $43,3 \%$ \\
\cline { 2 - 4 } Minum Obat & Teratur & 51 & $56,7 \%$ \\
\hline Umur & $15-29$ tahun & 35 & $38,9 \%$ \\
\cline { 2 - 4 } & $<15$ dan $>29$ & 55 & $61,1 \%$ \\
\hline \multirow{2}{*}{ Jenis Kelamin } & Laki-Laki & 76 & $84,4 \%$ \\
\cline { 2 - 4 } & Perempuan & 14 & $15,6 \%$ \\
\hline \multirow{3}{*}{ Pengetahuan } & Kurang & 57 & $63,3 \%$ \\
\hline \multirow{3}{*}{ Pendidikan } & Baik & 33 & $36,7 \%$ \\
\hline \multirow{3}{*}{ Sikap } & Rendah & 68 & $75,6 \%$ \\
\hline Dukungan Petugas & Tinggi & 22 & $24,4 \%$ \\
\cline { 2 - 4 } Kesehatan & Negatif & 49 & $54,4 \%$ \\
\hline \multirow{2}{*}{ Dukungan Keluarga } & Positif & 41 & $31,1 \%$ \\
\cline { 2 - 4 } & Kurang mendukung & 28 & $68,9 \%$ \\
\cline { 2 - 4 } & Kurang mendukung & 62 & $42,2 \%$ \\
\cline { 2 - 4 } Tingkat Ekonomi & Mendukung & 52 & $84,8 \%$ \\
\cline { 2 - 4 } & Rendah & 76 & $15,6 \%$ \\
\hline
\end{tabular}

\section{Analisis Bivariat}

Dalam analisis bivariat ini peneliti menggunakan uji Chi-Square oleh karena semua variabel berbentuk kategorik dengan masing masing 2 kelompok kategori. Untuk lebih jelas, hasil penelitian bivariat dipaparkan dalam tabel 2. 
Tabel 2

Analisis Bivariat Ketidakteraturan Minum Obat MDT Pada Penderita Kusta Dirumah Sakit Dr Sitanala Tangerang Banten

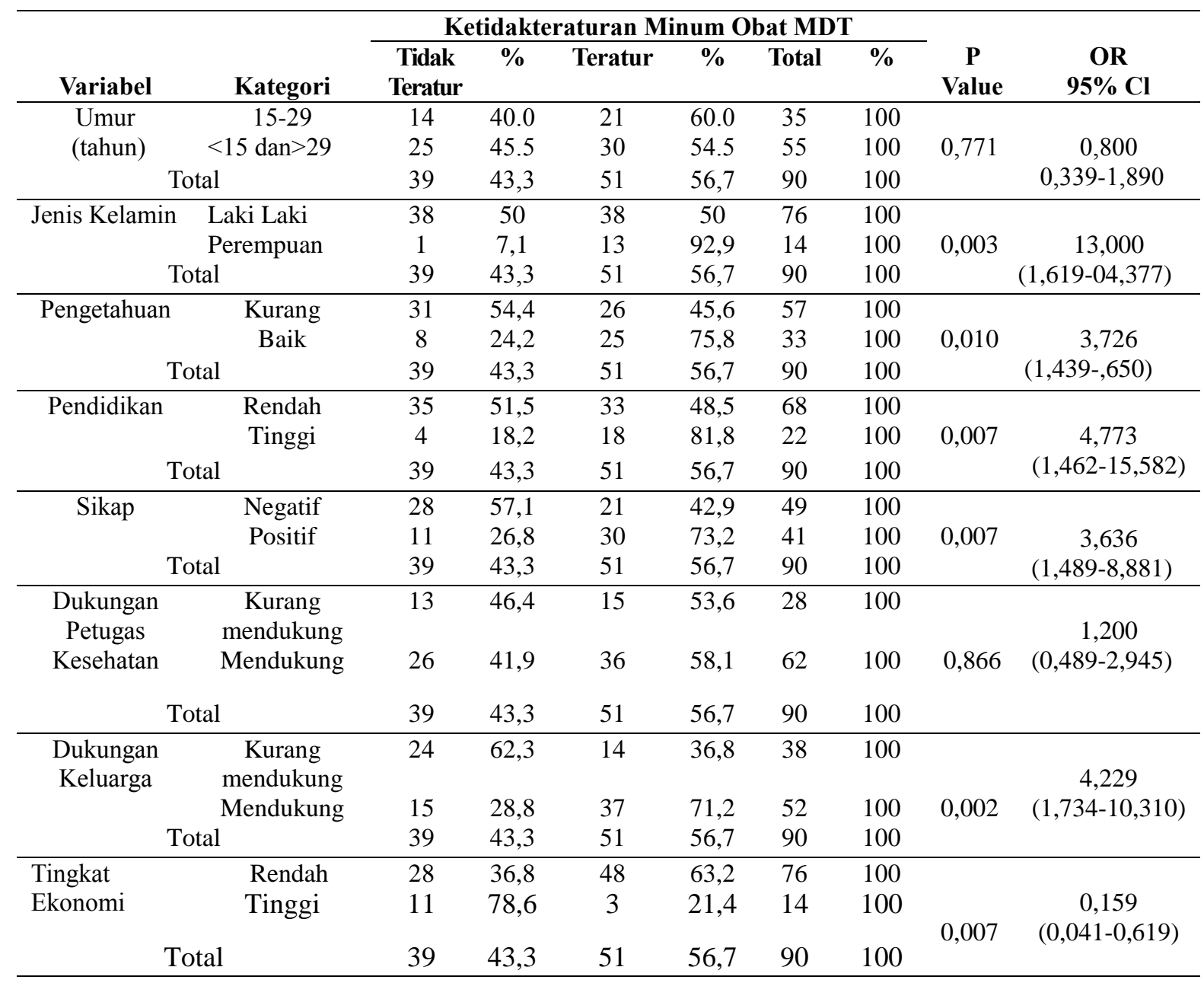

Berdasarkan hasil Uji maka proporsi maupun hubungan variabel independen (Umur, Jenis Kelamin, Pengetahuan, Tingkat Pendidikan, Sikap, Dukungan Petugas Kesehatan, Dukungan Keluarga,dan Tingkat Ekonomi) dengan variabel dependen (Ketidakterturan Minum Obat ) dapat dibahas sebagai berikut:

\section{Umur Penderita Kusta Terhadap Ketidakteraturan Minum Obat MDT}

Umur merupakan salah satu karakteristik tentang orang yang sangat utama. Umur mempunyai hubungan dengan tingkat keterpaparan besarta risk, serta sifat resistensi dan pengambilan keputusan juga dipengaruhi oleh umur tersebut.

Dalam penelitian ini, hasil uji statistik memperlihatkan adanya ketidakbermaknaan antara umur dengan Ketidakteraturan minum obat MDT, dimana nilai $\mathrm{P}$ value yang dihasilkan sebesar 0,777 artinya $\mathrm{P}$ value lebih besar dari alpha 0,05. Ketidakbermaknaan ini mungkin disebabkan bahwa adanya motivasi baik itu dari luar maupun dari dalam diri mereka, disaat mereka menjalani perawatan, memungkinkan mereka dapat patuh minum obat MDT.

Hasil penelitian ini tidak sejalan dengan penelitan Masduki. A yang mengungkapkan bahwa tingkat kepatuhan berobat lebih tinggi pada anak-anak dibandingkan dengan dewasa, namun sejalan dengan hasil penelitian 
Oesman tahun 1993 di kabupaten tangerang dan Basaria Hutabarat tahun 2007 di kabupaten Asahan, yang menyatakan bahwa tidak ada pengaruh antara umur dengan keteraturan berobat. (Soedarjatmi, 2009)

Hasil penelitian ini juga mematahkan pendapat para ahli maupun hasil penelitian sebelumnya bahwa mereka yang tidak patuh bisanya berusia produktif. Penelitian ini membuktikan bahwa untuk berperilaku minum obat MDT secara tidak teratur ternyata tidak hanya ditemukan pada usia produktif saja namun lebih banyak ditemukan pada usia tidak produktif. Menurut asumsi peneliti, hal ini mungkin dikarenakan pada umur produktif seseorang lebih banyak bergaul dengan media informasi sehingga cenderung lebih mendapatkan berbagi informasi, terutama tentang penyakit kusta memungkinkan ia lebih menyadari manfaat dari keteraturan minum obat MDT.

\section{Jenis Kelamin Penderita Kusta terhadap Ketidakteraturan minum obat MDT.}

Hasil analisis hubungan antara jenis kelamin dengan ketidakteraturan minum obat MDT, diketahui ternyata laki-laki lebih cenderung tidak teratur minum obat MDT ketimbang perempuan. Hal ini dibuktikan dengan diperolehnya nilai $\mathrm{P}$ value sebesar 0,003 dan OR : 13,000, CI : 1,619-04,377. Artinya reponden yang berjenis laki-laki mempunyai peluang untuk tidak teratur minum obat MDT sebesar 13 kali lebih besar dibanding responden yang berjenis kelamin laki-laki. Hasil penelitan ini mendukung temuan penelitian Soedarjatmi,et.all tahun 2009 yang menyatakan bahwa penderita kusta lebih banyak pada laki-laki yaitu 70,5\%, sedangkan perempuan 29,5\%. Sama halnya menurut Depkes 2012, distribusi epidemiologi kusta menurut jenis kelamin, dimana penyakit kusta lebih banyak menyerang laki-laki dari pada perempuan. Sama juga dengan pendapat Basaria Hutabarat tahun 2007, yang menyatakan bahwa kepatuhan minum obat berhubungan dengan factor individu penderita antara lain jenis kelamin.

Menurut asumsi penelitian adanya hubungan antara jenis kelamin dengan Ketidakteraturan minum obat MDT dalam penelitian ini, mungkin dikarenakan perempuan lebih cenderung merawat diri ketimbang laki-laki. Sesuai dengan kodratnya, seorang wanita untuk dapat berpenampilan menarik, ia akan berupaya mengatasi segala hal yang berhubungan dengan kecacatan pada tubuhnya. Sama halnya dengan gangguan penyakit yang berakibat buruk pada penampilannya, akan diupayakan untuk tidak terjadi dengan mematuhi segala anjuran termasuk teratur minum obat MDT.

\section{Pengetahuan Penderita Kusta Terhadap Ketidakteraturan Minum Obat MDT}

Pengetahuan adalah hasil "tahu" dan ini terjadi setelah orang melakukan penginderaan terhadap suatu objek tertentu. Penginderaan terjadi melalui pancaindera manusia, yakni; indra penglihatan, pendengaran, penciuman, rasa dan raba. Sebagian besar pengetaghuan manusaia diperoleh melalu mata dan telinga. Pengetahuan merupakan domain yang sangat penting untuk terbentuknya tindakan seseorang. Perilaku yang didasarkan pengetahuan lebih langgeng daripada perilaku yag tidak didasarkan oleh pengetahuan. (Notoatmodjo, 2010)

Ketidakteraturan minum obat MDT adalah salah satu bentuk perilaku dari pasien kusta. Dalam penelitian ini, hasil uji statistik memperlihatkan adanya hubungan antara pengetahuan dengan Ketidakteraturan minum obat MDT dengan P. Value : 0,010 dan $\mathrm{OR}=3,726 \mathrm{CI}: 1,439-, 650$. Artinya responden yang berpengetahuan kurang, mem[punyai peluang untuk tidak teratur minum obat MDT sebesar 3,7 kali dibanding reponden yang berpengetahuan baik. Dengan demikian maka dapat disimpulkan bahwa untuk berperilaku yang baik dan benar dalam hal teratur minum obat ternyata harus mempunyai pengetahuan yang cukup. 
Hasil penelitian ini mendukung teori L.Green, yang menyatakan, perilaku dipengaruhi oleh factor predisposisi (pengetahuan, sikap, dan persepsi), factor pemukin dan factor pendorong. Sama juga dengan pendapat Notoatmojo, pengetahuan merupakan dominan yang sangat penting untuk terbentuknya tindakan seseorang. (Notoatmodjo, 2010).

Hasil penelitian ini juga sejalan dengan hasil penelitian Masduki pada tahun 1993 yang mengatakan pengetahuan yang tinggi lebih teratur berobat dibandingkan dengan pengetahuan yang rendah.

Dari hasil peneltian ini, kemudian peneliti berasumsi bahwa orang yang mempunyai pengetahuan baik cenderung lebih berperilaku baik ketimbang orang yang berpengetahuan kurang. Tidak teratur dalam minum obat juga merupakan sebuah perilaku tidak baik yang dapat merugikan penderita itu sendiri.

\section{Pendidikan Penderita Kusta Terhadap Ketidakteraturan Minum Obat MDT}

Dalam penelitian ini, hasil uji statistik memperlihatkan adanya hubungan antara pendidikan dengan Ketidakteraturan minum obat MDT dengan P. Value : 0,007 dan OR =4,773 dengan CI: 1,462-15,582). Artinya responden yang berpendidikan rendah, mempunyai peluang untuk tidak teratur minum obat MDT sebesar 4,8 kali dibanding reponden yang berpendidikan tinggi. Hal ini sejalan dengan menurut Faiza M, menemukan bahwa kelompok tinggkat pendidikan tinggi lebih teratur berobat dari pada kelompok tingkat pendidikan rendah, sedangkan tingkat pendidikan rendah lebih sering tidak teratur berobat dibandingkan dengan kelompok tingkat pendidikan tinggi. Hasil penelitian ini juga sejalan dengan penelitian Masduki dikabupaten kuningan (1993) bahwa pendidikan mempunyai hubungan yang erat terhadap kepatuhan minum obat kusta. (Prastiwi, 2011)

Pendidikan merupakan proses belajar artinya di dalam pendidikan terjadi proses pertumbuhan, perkembangan kearah yang lebih baik dan lebih matang pada individu, kelompok dan masyarakat. Untuk mencapai tujuan tersebut individu, kelompok atau masyarakat tidak terlepas dari kegiatan belajar. seseorang dikatakan belajar apabila didalam dirinya terjadi perubahan dari yang tidak tahu menjadi tahu dan tidak dapat mengerjakan menjadi bisa dikerjakan.

Sama halnya dengan pendapat Notoatmojo (2010) bahwa pendidikan adalah suatu proses belajar yang berarti dalam pendidika itu terjadi proses pertumbuhan, perkembangan atau perubahan kearah yang lebih baik. Pendidikan sejalan dengan pengetahuan dimana pengetahuan merupakan hasil tahu dan ini terjadi setela seseorang melakukan pengindraan terhadap objek tertentu, dan bila penderita tahu minum obat teratur akan memperoleh kesembuhan, maka penderita akan patuh

Dari hasil penelitian ini disimpulkan bahwa untuk berperilaku yang baik dan benar ternyata harus mempunya pendidikan yang cukup, oleh karena tingkat pendidikan berperan penting dalam merubah perilaku seseorang. Ketidakteraturan penderita dalam hal minum obat merupakan contoh dari perilaku tidak baik yang patut untuk dihindari agar tidak merugikan penderita itu sendiri.

\section{Sikap Penderita Kusta Terhadap Ketidakteraturan Minum Obat MDT}

Hasil analisis hubungan antara sikap dengan kidakteraturan minum obat MDT, pada uji statistik didapatkan P. Value : 0,007 dan OR = 3,636 dengan CI: 1,489-8,881. sehingga disimpulkan secara statistik diperoleh hasil, adanya hubungan antara antara sikap dengan kidakteraturan minum obat MDT Pada Penderita Kusta Di Ruang Rawat Inap Rumah Sakit Kusta Dr. Sitanala Tangerang Banten. Berdasrkan nilai OR yang diperoleh, maka 
dapat disimpulkan bahwa responden yang mempunyai sikap negatif berpeluang untuk tidak teratur minum obat sebesar 3,6 kali dibanding responden yang bersikap positif.

Hasil penelitian ini sejalan dengan teori Thustone dan Litkert, bahwa sikap adalah bentuk evaluasi, reaksi yang mendukung, memihak atau tidak memihak pada objek tertentu. Sejalan juga dengan Hasil penelitian yang dilakukan oleh Fajar (2005) di Kabupaten Gresik pada penderita kusta, ada pengaruh sikap penderita terhadap pengobatan dini dan upaya pengobatan teratur oleh penderita kusta.

Adanya hubungan ini menurut asumsi peneliti, untuk berperilaku yang baik dan benar dalam hal ini teratur minum obat MDT sangat dipengaruhi oleh sikap. Hal ini berhubungan dengan terori dari Newcom yang adalah salah satu ahli psikologi social menyatakan bahwa sikap merupakan kesiapan atau kesediaan untuk bertindak. (Notoatmodjo, 2010)

Seorang penderita kusta akan teratur dalam minum obat MDT jika dalam dirinya ada kesiapan untuk merespon penyakit yang dideritanya. Ia juga akan bertindak (minum obat MDT) apabila ada motivasi, baik dari luar maupun dari dalam dirinya sendiri.

\section{Dukungan Petugas Kesehatan Terhadap Ketidakteraturan Minum Obat MDT}

Berbagai pendapat maupun hasil penelitian menyatakan bahwa keberhasilan dari suatu pengobatan dalam hal ini adalah pengobatan kusta, erat kaitannya dengan peran berbagai pihak, salah satunya adalah petugas kesehatan. Dukungan petugas kesehatan akan menjadi motivasi untuk sembuh bagi seorang penderita, sehingga hal ini berpengaruh pada keinginan penderita untuk patuh dalam minum obat. Namun dalam penelitian ini, secara statistik diperoleh hasil tidak ada hubungan antara Dukungan Petugas Kesehatan Terhadap Ketidakteraturan Minum Obat MDT Pada Penderita Kusta, dimana P value yang diperoleh sebesar 0,866 artinya $\mathrm{P}$ value > alpha 0,05 .

Hasil penelitian ini tidak sejalan atau mematakan penelitian yang dilakukan oleh Masduki tahun 2007 yang mengungkapkan bahwa peran petugas mempunyai hubungan yang bermakna terhadap ketidakteraturan berobat pada penderita kusta. (Teddy, 2010)

Menurut asumsi peneliti, bahwa untuk berperilaku yang baik dan benar dalam hal teratur minum obat MDT tidak harus didukung oleh petugas kesehatan namun dibutuhkan kesadaran dan kemauan dari dalam diri penderita itu sendiri.Seseorang akan berperilaku secara baik dan benar, jika memiliki kemauan dan kesadaran. Kemauan dan kesadaran itu bisa saja termotivasi oleh lingkungan maupun keinginan dari dalam dirinya sendiri.

\section{Dukungan Keluarga Penderita Kusta Terhadap Ketidakteraturan Minum Obat MDT}

Hasil penelitian meperlihatkan antara Dukungan Keluarga Penderita Kusta Terhadap Ketidakteraturan Minum Obat MDT Pada Penderita Kusta memiliki hubungan yang erat. Hal ini dibuktikan dengan hasil uji statistik yang memperlihatkan $\mathrm{p}$ value sebesar 0,002. Hasil penelitian inipun diperkuat dengan nilai Odd Ratio sebesar 4,229 dengan CI: (1,734-10,310) yang artinya para penderita yang menyatakan kurang ada dukungan dari keluarga mempunyai peluang 4 kali lebih besar untuk tidak teratur minum obat MDT dibandingkan dengan penderita yang menyatakan ada dukungan dari keluarga.

Hasil penelitian ini sejalan dengan penelitian Basaria Hutabarat tahun 2007 yang menyatakan bahwa peran keluarga mempengaruhi keteraturan minum obat kusta. Banyaknya penderita kusta yang tidak mendapatkan 
dukungan dari keluarganya sangat memungkinkan penderita menjadi frustasi sehingga merasa hidupnya sudah tidak berarti lagi. Hal ini berdampak pada keberhasilan dari pengobatan oleh karena penderita tidak patuh dalam minum obat. (Teddy, 2010)

Adanya hubungan ini menurut asumsi peneliti bahwa Keluarga adalah orang yang terdekat secara ikatan batin, oleh karena itu jika seseorang mendapatkan dukungan dari keluarga dalam hal apapun, secara mental akan berpengaruh. Dalam hal kepatuhan minum obat, Dukungan dari keluarga bisa menjadi doktin bagi seseorang penderita kusta untuk patuh dan punya keinginan untuk sembuh.

\section{Tingkat Ekonomi Terhadap Ketidakteraturan Minum Obat MDT}

Permasalahan tingkat ekonomi seringkali di hubungannya dengan berbagai masalah kesehatan. Dalam penelitian ini, peneliti mencoba menghubungkan antara tingkat ekonomi dengan Ketidakteraturan minum obat MDT pada penderita Kusta. Hasil penelitian, secara statistik diperoleh nilai p value lebih kecil dari nilai alpha yaitu 0,007 sehingga dapat disimpulkan ada hubungan yang bermakna antara tingkat ekonomi dengan ketidakteraturan minum obat MDT pada penderita kusta. Nilai OR yang dipeorleh sebesar 0,2 artinya penderita dengan tingkat ekonomi tinggi mempunyai peluang tidak teratur minum obat MDT sebanyak 0,2 kali lebih kecil dibandingkan dengan penderita yang mempunyai tingkat ekonomi rendah.

Namun Hasil penelitian ini tidak sejalan dengan penelitian Komaria (1998) yang manyatakan bahwa tidak ada hubungan yang bermakna antara tingkat ekonomi dengan kepatuhan minum obat. Tidak sejalan dengan penelitian Basaria Hutabarat tahun 2007 yang menyatakan bahwa tidak ada pengaru antara tingkat ekonomi dengan kepatuhan minum obat kusta. (Teddy, 2010)

Hasil penelitian kali ini membuktikan bahwa untuk teratur minum obat, ternyata ada kaitannya dengan tingkat ekonomi. Menurut asumsi peneliti, hal ini mungkin juga dikarenakan seseorang yang memiliki tingkat ekonomi tinggi, pada umumnya memiliki pengetahuan yang baik, dan oleh karena pengetahuannya yang baik memungkinkan dia lebih cenderung berperilaku yang baik pula.

\section{KESIMPULAN DAN SARAN}

Berdasarkan hasil penelitian tentang Ketidak-teraturan minum obat MDT di Ruang Rawat Inap Rumah Sakit Dr. Sitanala Tangerang Banten maka dapat disimpulkan bahwa jumlah penderita yang tidak teratur minum obat MDT sebanyak 39 orang (43,3\%) dan yang teratur minum obat MDT sebanyak 51 orang (56,7\%) (Data sekunder). Hasil uji statistik menunjukan ada 6 variabel yang berhubungan yaitu Jenis Kelamin dengan P value : 0,003 dan OR : 13,000, CI : 1,619-04,377, Pengetahuan dengan P. Value : 0,010 dan OR = 3,726 CI : 1,439,650, Pendidikan dengan P. Value : 0,007 dan OR = 4,773 dengan CI: 1,462-15,582), Sikap dengan P. Value : 0,007 dan OR = 3,636 dengan CI: 1,489-8,881, Dukungan Keluarga dengan P Value : 0,002 dan OR = 4,229 dengan CI: (1,734-10,310), Tingkat Ekonomi dengan P.value :0,007 dan OR:0,159 dengan CI: 0,041-0,619. Sementara variabel yang tidak berhubungan ada 2 yaitu Umur, dengan P. Value : 0,777 dan Dukungan petugas kesehatan dengan P Value : 0,866. Rekomendasi yang dapat diberikan adalah Bagi petugas kesehatan agar tetap memberikan dukungan kepada penderita dalam hal memberikan motivasi atau dorongan agar penderita bisa berperilaku sesuai dengan arahan yang diberikan. Hendaknya dalam memberikan informasi, seorang petugas 
harus menggunakan bahasa yang mudah dimengerti karena penderita pada umumnya berpendidikan rendah. Perlu juga dilakukan KIE (komunikasi, informasi, dan edukasi) tentang kepatuhan meminum obat MDT kepada penderita kusta sebagai upaya penyembuhan dan pencegahan timbulnya cacat primer dan sekunder, sehingga penderita yang tidak patuh meminum obat khususnya bagi laki-laki, lebih termotivasi dalam penyembuhan penyakitnya. Untuk keluarga agar dapat menerima, memberikan dorongan dan semangat agar penderita kusta dapat teratur minum obat MDT sampai dinyatakan sembuh secara medis.

\section{DAFTAR PUSTAKA}

1. Agung, M. (2010). Hubungan Persepsi Pasien Tentang Pelaksanaan Komunikasi, Informasi Dan Edukasi (KIE) Perawat dengan Kepatuhan Berobat Pada Penderita Kusta Dipoliklinik Kusta RSK. Sitanala Tangerang. Riset Keperawatan: Tangerang: STIKes Widya Dharma Husada.

2. Beni, N. S. (2012). 70 Persen Penderita Kusta, Warga Miskin. Retrieved Juli 02, 2012, from http://Serang, kompas.html

3. Depkes. (2012). Pedomaan Nasional Program Pengendalian Penyakit Kusta: Dit Jen PPM \& PL. Jakarta: Depkes RI.

4. Dinkes Banten. (2012.). Profil Kesehatan 2012 Kabupaten/Kota Se-Provinsi Banten. Serang: Dinkes Banten.

5. Hastono, S. P. (2007). Analisis Data Kesehatan. Depok: Fakultas Kesehatan Masyarakat Universitas Indonesia.

6. Hutabarat, B. (2007). Pengaruh Faktor Internal dan Eksternal Terhadap Kepatuhan Minum Obat Pada Penderita Kusta di Kabupaten Asahan Tahun 2007. Tesis. Medan: Universitas Sumatera Utara.

7. Notoatmodjo, S. (2010). Ilmu Perilaku Kesehatan. Jakarta: Rineka Cipta.

8. Prastiwi, T. (2011). Faktor- faktor Yang Berhubungan Dengan Cacat Tingkat II Pada Penderita Kusta Di RS Kusta Kediri Jatim. Skripsi. Surabaya. Surabaya: Fakultas Kesehatan Masyarakat Universitas Airlangga.

9. RSK Dr. Sitanala. (2012). Profil Rumah Sakit Kusta Dr. Sitanala. Tangerang. Tangerang: RSK Dr. Sitanala.

10. Soedarjatmi, e. (2009). Faktor-Faktor yang Melatarbelakangi Persepsi Penderita Terhadap Stigma Penyakit Kusta. Jurnal Promosi Kesehatan Indonesia, volume 4 no. 12009.

11. Teddy, S. (2010). Faktor-Faktor Yang Berhubungan Dengan Kepatuhan Minum Obat (MDT) Multi Drug Therafi Pada Pasien Kusta Di Ruang rawat Inap RSK.Dr. Sitanala Tangerang. Riset Keperawatan. Tangerang: STIKes Widya Dharma Husada.

12. WHO. (2011, September 02). Weekly Epidemiological Record, Genève. Leprosy update, 2011, pp. 389-400. 